\title{
Metabolite-Targeted Analysis and Physiological Traits of Zea mays L. in Response to Application of a Leonardite-Humate and Lignosulfonate-Based Products for Their Evaluation as Potential Biostimulants
}

\author{
Andrea Ertani ${ }^{1}\left(\mathbb{D}\right.$, Serenella Nardi ${ }^{1, *} \mathbb{C}$, Ornella Francioso ${ }^{2}$, Diego Pizzeghello ${ }^{1} \mathbb{C}$, Anna Tinti ${ }^{2}$ \\ and Michela Schiavon ${ }^{1}$ \\ 1 Department of Agronomy, Food, Natural resources, Animals and Environment (DAFNAE), \\ University of Padua, 35100 Padua, Italy \\ 2 Department of Agricultural and Food Sciences, Alma Mater Studiorum-University of Bologna, \\ Viale Fanin 40, 40127 Bologna, Italy \\ 3 Department of Biomedical and Neuromotor Sciences, Alma Mater Studiorum-University of Bologna, \\ Via Belmeloro 8/2, 40126 Bologna, Italy \\ * Correspondence: serenella.nardi@unipd.it; Tel.: +39-0498272911
}

Received: 24 June 2019; Accepted: 9 August 2019; Published: 12 August 2019

\begin{abstract}
The main aim of this study is to identify and investigate specific humates (Hs) as potential biostimulants. Five specialty lignosulfonates (LS1-5), one commercial leonardite-humate (PH), and one commercial lignosulfonate (LH), were analyzed for their carbon, nitrogen, and sulfur contents, and the distribution of functional groups using Fourier transform infrared (FTIR) and Raman spectroscopies. Hs were further supplied for two days to Zea mays L. in hydroponics to test their capacity to trigger changes in physiological target-responses. LS1, LS2, LS3, and LS5 determined the most pronounced effects on plant growth and accumulation of proteins and phenolics, perhaps because of their chemical and spectroscopic features. Root growth was more increased $(+51-140 \%)$ than leaf growth $(+5-35 \%)$. This effect was ascribed to higher stimulation of $\mathrm{N}$ metabolism in roots according to the increased activity of $\mathrm{N}$-assimilation enzymes (GS and GOGAT) and high consumption of sugars for energy-dependent processes. Increased values of RuBisCO, SPAD (Soil Plant Analysis Development values), and leaf sugar accumulation refer to enhanced photosynthesis attributed to Hs. We conclude that Hs tested in this study functioned as biostimulants, but the specialty lignosulfonates were more efficient in this role, possibly because of the type of starting material and process used for their production, which may have influenced their chemical properties.
\end{abstract}

Keywords: Zea mays L; lignohumate; lignosulfonate; biological activity; nitrogen metabolism; carbon metabolism; proteins; phenolics; sugars

\section{Introduction}

Increasing food production for a developing world population and the protection of environmental resources represents a great challenge in the field of agricultural sciences. Traditional agronomical practices especially have negatively impacted a number of environmental aspects and have been in part responsible for soil and water pollution [1]. In addition, the quality of most agricultural soils has long been injured by the thorough application of mineral fertilizers in order to achieve high crop yield requirements [2]. 
The decline of soil chemical and physical properties is generally accompanied by the decrease of soil fertility, a reduced content of soil organic carbon, and the impoverishment of microbial communities' biodiversity [3]. Therefore, new advances in support of environmentally friendly crop productions are required. Among them, one potential strategy could be the application of biostimulant products during crop cultivation [4]. Biostimulants are "formulated products of biological origin, either with or without plant growth promoting microorganisms (PGPMs), able to stimulate plant productivity at very low dosages by virtue of synergic effects of the different bioactive constituents" [5]. Biostimulants promote plant nutrition and tolerance to environmental stresses [6,7] and, based on their origin and the starting source for their manufacturing, they are divided in different groups, as follows: Humic substances (HS), seaweed extracts, protein hydrolysates, and microbial inoculants, such as mycorrhizal fungi and rhizobacteria, and beneficial elements [8]

Humic substances or humates are regarded as a major category of biostimulants, with a big market share [9]. They represent the most stable and recalcitrant component of soil organic matter and derive from the chemical and microbial degradation of vegetal and animal residues $[10,11]$. They are useful for improving the quality of soils, as well as the plant metabolism and root morphological traits, via their interaction with a plurality of biochemical mechanisms and physiological processes occurring at the plant-soil interface $[10,11]$. Specifically, humic substances stimulate plant growth via hormone-like effects and increased photosynthesis efficiency, enhance the respiration rate, and improve root nutrient uptake through an effect, either direct or indirect, on the expression of genes encoding $\mathrm{H}^{+}$-ATPase isoforms and membrane transporters [7,10-12].

Over the last decades, commercial humic products designed lignohumates have found various applications in environmental technologies and agriculture $[13,14]$ and are commonly used for several industrial purposes [14]. They share similar properties with humic substances in terms of chelation, buffering, and cation exchange capacity because of the great number of carboxylic and phenol groups bonded to the aromatic ring [10,15]. Lignohumates are water soluble anionic polymers containing high and low molecular weight molecules, as well as a large number of charged groups, and are by-products generated from the sulphite process of wood, in which fibers of cellulose are separated from lignin by the action of bisulphite $[16,17]$. The lignin fraction in wood is sulfonated, degraded and solubilized in water during this procedure [18]. In this way, the production of humates from materials that do not primarily contain them becomes a very fast process, which otherwise would naturally take many years. Researches have only clarified the primary structure of these polymers in part, so far, and only a few studies have investigated their effects on plant growth and metabolism [19-21].

The production of humates derived from different salts of humic acids, such as ammonium humates and potassium $(\mathrm{K})$ humates is increasingly growing. Potassium humates, in particular, are used as biostimulants to ameliorate soil chemical, physical, and biological properties, such as the content of organic matter, water retention capacity, structure, deactivation of toxic metals, and microbiome. In addition, they can increase the efficiency of inorganic fertilizers by prompting plant growth, yield and quality, enhancing nutrient uptake and assimilation, and promoting plant resistance to stress conditions [22-27].

Interestingly, the chemistry and physiological functioning of humates can vary depending on the starting material (e.g., leonardite, wood) from which they originate, extraction processes $(\mathrm{KOH}$ extraction for leonardite, wood bisulphite extraction for lignosulfonates) and modification technologies used to obtain the products. Indeed, humates derived from the same source and obtained by the same company can widely differ in composition [28]. On this account and in view of the plant diversity from which humates can be produced, it appears relevant to characterize the marketed products to test their effectivity in agriculture as biostimulants.

In light of such considerations, seven humates were investigated in this study to evaluate their biostimulant potential. The humates included a commercial lignosulfonate-based product (LH, LignoHumate ${ }^{\circledR}$, produced using a patented oxidation process) consisting of a highly concentrated plant and soil amendment, a commercial humate extracted from leonardite $(\mathrm{PH})$, produced and marketed by 
Borregaard. The remaining humates (LS1, LS2, LS3, LS4, LS5) were specialty lignosulfonates developed by Borregaard and applying proprietary technology (different from the one used to obtain LH) to modify the starting material. We first assayed differences in their content of main elements $(C, N$, and S), and in the occurrence and distribution of principal functional groups using two complementary spectroscopic techniques (FT-IR and FT-Raman). Then, we applied these products to Zea mays L. plants in order to evaluate differences in their capacity to trigger positive changes in physiological and biochemical traits associated with plant productivity. We chose to test the products on Zea mays $\mathrm{L}$. because it is a relevant staple crop for many populations worldwide. One of the novelties of the study is that most of products tested in this study were specialty lignosulfonates developed by Borregaard's company using proprietary technology and, thus, they were supposed to be very different in chemical features from standard lignosulfonates.

\section{Results}

\subsection{Chemical and Spectroscopic Features of Hs}

The elemental composition in percent content $(\mathrm{w} / \mathrm{w})$ of Hs is reported in Table 1. Carbon (C) content was strongly correlated $\left(R^{2}=0.83\right)$ with nitrogen $(\mathrm{N})$ content for all $\mathrm{Hs}$ and varied from $33.04 \%$ $(\mathrm{w} / \mathrm{w})$ in LH to $54.56 \%(\mathrm{w} / \mathrm{w})$ in LS1. Nitrogen content was also maximum in LS1 $(2.18 \% \mathrm{w} / \mathrm{w})$, but minimum in LS4 $(1.58 \% \mathrm{w} / \mathrm{w})$. Sulfur (S) content was low only in $\mathrm{PH}(1.30 \%)$, while it was higher in lignosulfonates, varying from $5.13 \%(w / w)$ in LS5 to $7.83 \%(w / w)$ in LS4.

Table 1. Elemental analysis of carbon (C), nitrogen (N), and sulfur (S) in the different humates.

\begin{tabular}{cccc}
\hline Product & $\mathbf{C}$ & $\mathbf{N}$ & $\mathbf{S}$ \\
\hline & & $\%(w / w)$ & \\
\hline LS1 & $54.56 \pm 1.02$ & $2.18 \pm 0.13$ & $5.56 \pm 0.34$ \\
LS2 & $41.08 \pm 1.10$ & $1.70 \pm 0.15$ & $6.12 \pm 0.40$ \\
LS3 & $41.28 \pm 1.32$ & $1.95 \pm 0.21$ & $5.49 \pm 0.12$ \\
LS4 & $37.11 \pm 1.15$ & $1.58 \pm 0.17$ & $7.83 \pm 0.21$ \\
LS5 & $48.15 \pm 1.50$ & $2.12 \pm 0.13$ & $5.13 \pm 0.34$ \\
PH & $38.05 \pm 1.01$ & $1.67 \pm 0.20$ & $1.30 \pm 0.23$ \\
LH & $33.04 \pm 1.14$ & $1.64 \pm 0.22$ & $5.33 \pm 0.31$ \\
\hline
\end{tabular}

FTIR and Raman analyses were performed to evaluate the main chemical attributes of Hs. The attributions of the main peaks for different functional groups identified in the FTIR and Raman spectra were mainly obtained by references [29]. With respect to FTIR spectra, we decided to display only the peak fitting results obtained in the region from 1800 to $1370 \mathrm{~cm}^{-1}$, because the main differences in variation were observed in this region. The region between $1200 \mathrm{~cm}^{-1}$ and $1000 \mathrm{~cm}^{-1}$ was heavily dominated by strong bands, probably originated by the $\mathrm{SO}_{3} \mathrm{H}$ group vibrations (Figure 1) [30]. 

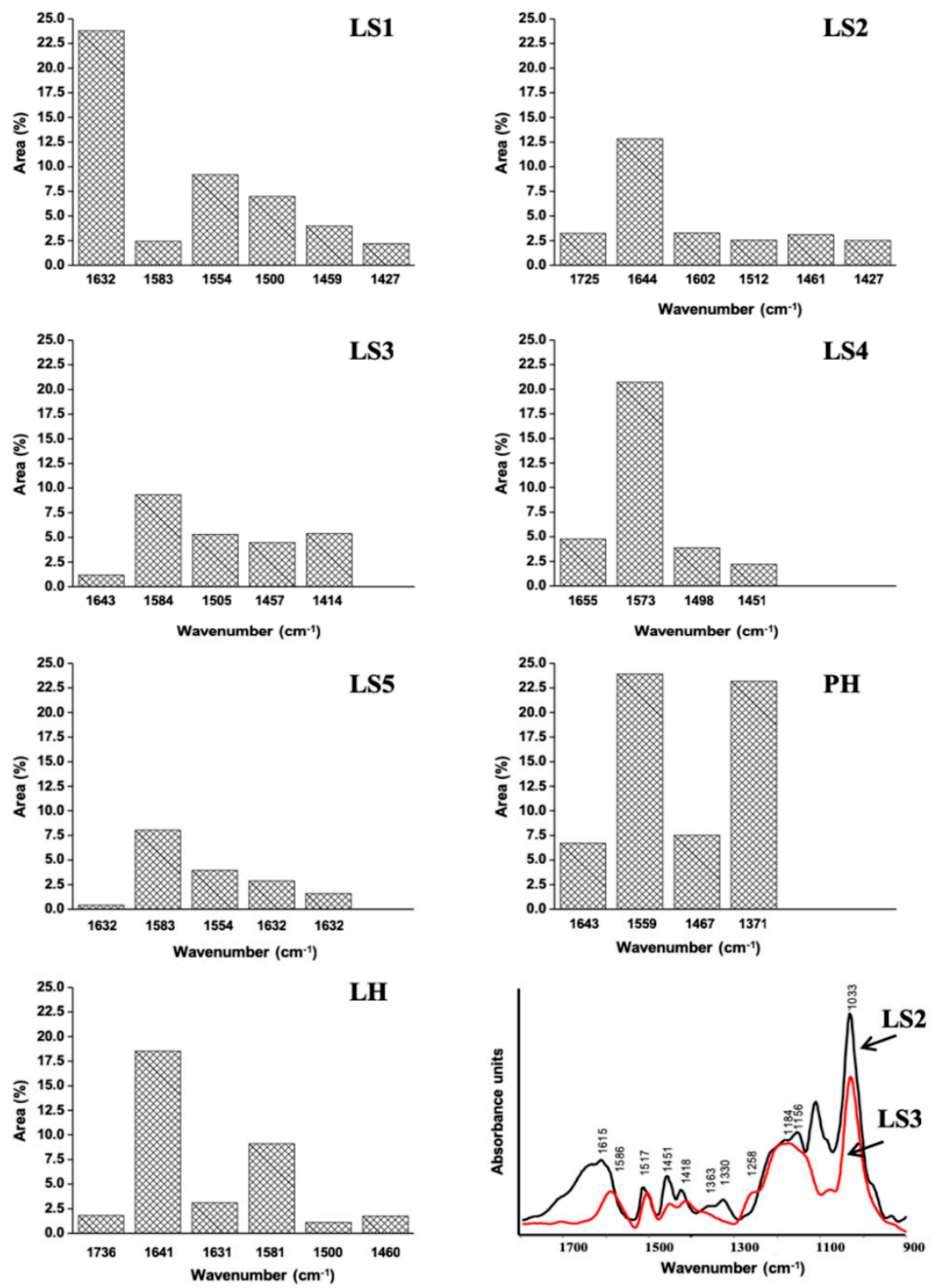

Figure 1. FTIR histograms of humates (Hs) peak areas processes by using curve fitting (from 1800 to $\left.1370 \mathrm{~cm}^{-1}\right)$.

In LS2 and LH, due to $\mathrm{C}=\mathrm{O}$ bonds of acetyl ester from residual hemicelluloses, a band between 1735 and $1725 \mathrm{~cm}^{-1}$ was evident. A very weak band at $1705 \mathrm{~cm}^{-1}$ was observed only in LS5. This band, associated with those at 1258 and $1418 \mathrm{~cm}^{-1}$, may be attributed to the $\mathrm{C}=\mathrm{O}$ stretching of $\mathrm{COOH}$ groups, while the other two bands may be due to $C(=\mathrm{O}) \backslash \mathrm{O}$ stretching vibration and $\mathrm{OH}$ in-plane deformation vibrations, respectively (spectra not shown). The appearance of carboxyl acid groups could be related to the removal of hemicellulose in this sample [31]. The bands at 1644 in LS2, LS3, $\mathrm{LH}$, and $\mathrm{PH}$, and at $1632 \mathrm{~cm}^{-1}$ in LS1 and $\mathrm{LH}$, were likely associated with $\mathrm{H}_{2} \mathrm{O}$ and $\mathrm{C}=\mathrm{O}$ stretching in conjugated $p$-substituted aryl ketones [32]. In addition, the peak at $1655 \mathrm{~cm}^{-1}$ recorded in LS4 could be assigned to $\mathrm{C}=\mathrm{O}$ in alkyl groups of the lignin side chains, conjugated with the aromatic rings [33]. These bands were completely absent in LS5. Other bands identified between 1600 and $1573 \mathrm{~cm}^{-1}$ corresponded to vibration of aromatic rings. The intensity of these bands depends on the number of $\mathrm{C}-\mathrm{O}$ bonds to the aromatic ring [34]. Intermolecular aromatic $\mathrm{C}=\mathrm{C}$ bonds may also have contributed to the intensity of these bands. The peaks from 1512 to $1498 \mathrm{~cm}^{-1}$ are typical of the skeletal and stretching vibration of aromatic moieties in lignin. Such peaks were present in all products. The bands at around 
1460 and $1414 \mathrm{~cm}^{-1}$ were attributed to the bending vibration of the methoxyl on benzene rings and methylene groups, respectively. The peak at $1370 \mathrm{~cm}^{-1}$, observed only in $\mathrm{PH}$, may be due to aromatic $\mathrm{CH}$ generated by cleavage of ether bonds within the lignin (spectra not shown).

The relative area percentage gave an estimation of the functional group distribution in the Hs (Figure 1). The band at around $1640 \mathrm{~cm}^{-1}$ showed a variable distribution among products. For instance, it was dominant in LS1 (24\%), LH (18\%), LS2 (13\%), and totally absent in LS5. The aromatic structure was diversified into different bands at around 1580,1559, and $1500 \mathrm{~cm}^{-1}$. The first band was dominant in LS4 (21\%), LS3 (9.4\%), and LH (9.0\%), and absent in PH. In the other products, this band ranged from $8 \%$ to $2.4 \%$. The second band at $1559 \mathrm{~cm}^{-1}$ accounted for $24 \%$ in $\mathrm{PH}$ and $9 \%$ in LS1. The last band at around $1500 \mathrm{~cm}^{-1}$ was prevalent in PH $(7.5 \%), \mathrm{LS} 1(7 \%)$, and LS3 (5\%). In other lignosulfonates, it varied from $4 \%$ in LS4 and LS5, 2.5\% in LS2, and 1\% in LH. Finally, the band at $1371 \mathrm{~cm}^{-1}$ accounted for $23 \%$ in the commercial humate $\mathrm{PH}$.

The Raman spectra of LS2 and LS5 are reported in Figure 2, while the complete attributions of the two lignosulfonates are shown in Table 2. Both spectra display bands at 3490 and $3250 \mathrm{~cm}^{-1}$, attributable to $\mathrm{OH}$ stretching free or $\mathrm{H}$-bonded, respectively, and both aliphatic (at 2940 and $2846 \mathrm{~cm}^{-1}$ ) and aromatic (at $3070 \mathrm{~cm}^{-1}$ ) CH stretching in the higher wavenumber region. Moreover, the shoulder at about $1670 \mathrm{~cm}^{-1}$ could be ascribed to conjugated $C=O$ stretching [35], the bands at 1630, 1604, and about $1500 \mathrm{~cm}^{-1}$, together with that one at $1190 \mathrm{~cm}^{-1}$, were all attributable to phenolic rings, the last one specifically to lignin $[35,36]$. The peaks at 1460,1370 , and $1330 \mathrm{~cm}^{-1}$ corresponded to bending vibrations of $\mathrm{O}-\mathrm{CH}_{3}, \mathrm{CH}$, and aliphatic $\mathrm{OH}$ in lignin and cellulose, respectively [35]. The peaks at 1284 and $1082 \mathrm{~cm}^{-1}$, together with that recorded at $815 \mathrm{~cm}^{-1}$ indicated the presence of sulfated groups $[37,38]$. Other bands observed in the Raman spectra were less indicative to identify the functional groups present in LS2 and LS5. The relative intensity of the over reported bands is different in the two examined spectra. In particular, for LS5 the bands attributable to aromatic groups (at 3070, 1633, 1604, and $1190 \mathrm{~cm}^{-1}$ ) displayed a higher intensity compared to LS2, indicating that the aromatic component was higher in LS5. On the contrary, the bands at 1330 and $898 \mathrm{~cm}^{-1}$, both attributable to cellulose, were more intense in LS2, indicating a higher content of this component in LS2 compared to LS5.
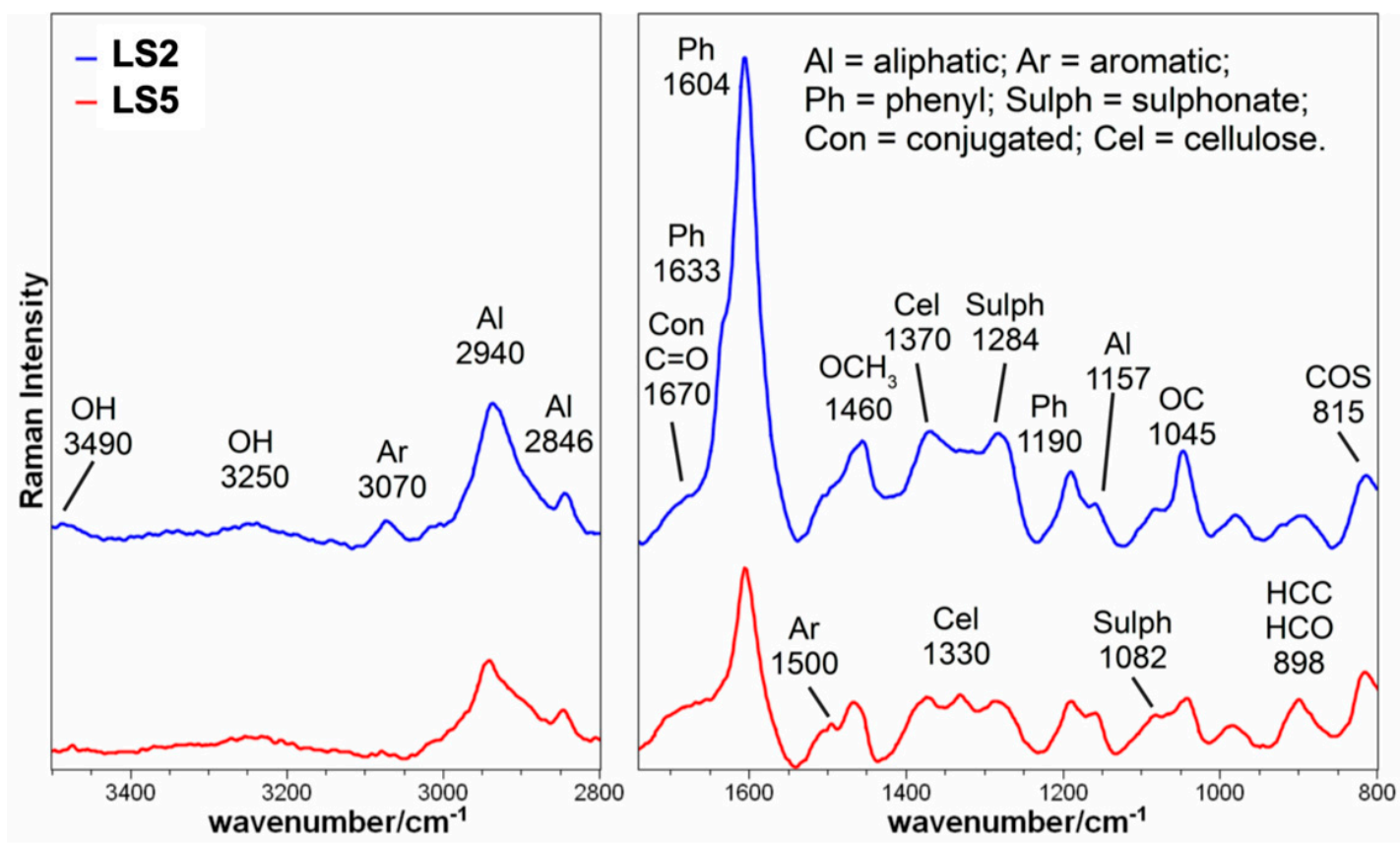

Figure 2. FT-RAMAN spectra of lignosulfonates LS2 and LS5. 
Table 2. Main bands observed in the Raman spectra of humates LS2 and LS5. S = strong; $\mathrm{m}=$ medium; $\mathrm{w}=$ weak; $\mathrm{v}=$ very; $\mathrm{sh}=$ shoulder.

\begin{tabular}{|c|c|c|}
\hline Attributions & LS2 & LS5 \\
\hline $\mathrm{OH}$ stretching & $3490 \mathrm{w}$ & $3490 \mathrm{vw}$ \\
\hline $\mathrm{OH}$ stretching & $3250 \mathrm{w}$ & $3250 \mathrm{w}$ \\
\hline Aromatic $\mathrm{CH}$ stretching & $3070 \mathrm{w}$ & $3070 \mathrm{vw}$ \\
\hline Aliphatic $\mathrm{CH}$ stretching & $2940 \mathrm{~m}$ & $2940 \mathrm{w}$ \\
\hline Aliphatic $\mathrm{CH}$ stretching & $2846 \mathrm{~m}-\mathrm{W}$ & $2846 \mathrm{~m}-\mathrm{w}$ \\
\hline 1670 conjugated $\mathrm{C}=\mathrm{O}$ & 1670 w. sh & 1670 w. sh \\
\hline Phenolic peak & 1633 s. sh & \\
\hline Aryl ring stretch, symmetric (lignin); Phenolic peak & $1604 \mathrm{vs}$ & $1604 \mathrm{~s}$ \\
\hline $\mathrm{C}_{\mathrm{ar}}-\mathrm{H}$ in plane bend, $\mathrm{CO}(\mathrm{H})$ str. & About 1500 vw. sh & About 1500 w. sh \\
\hline $\mathrm{CH}_{3}$ bending in $\mathrm{OCH}_{3}$ (lignin and carbohydrates) & $1460 \mathrm{~m}-\mathrm{W}$ & $1460 \mathrm{vw}$ \\
\hline $\mathrm{C}-\mathrm{H}$ bend in $\mathrm{R}_{3} \mathrm{C}-\mathrm{H}$ (cellulose) & $1370 \mathrm{~m}$ & $1370 \mathrm{~m}$ \\
\hline Aliphatic O-H bend (cellulose) & & $1330 \mathrm{~m}$ \\
\hline Sulfate group, asymmetric stretching & $1284 \mathrm{~m}$ & $1284 \mathrm{~m}$ \\
\hline Phenol (lignin) & $1190 \mathrm{~m}-\mathrm{w}$ & $1190 \mathrm{~m}-\mathrm{w}$ \\
\hline C-C skeletal mode $\mathrm{OCH}_{3}$ loop rocking & 1157 w. sh & 1157 w. sh \\
\hline Sulfate group, symmetric stretching & 1082 w. sh & $1082 \mathrm{~m}-\mathrm{w} . \mathrm{sh}$ \\
\hline $\mathrm{OC}\left(\mathrm{H}_{3}\right)$ stretching and rocking & $1045 \mathrm{~m}$ & $1045 \mathrm{~m}$ \\
\hline $\mathrm{H}-\mathrm{C}-\mathrm{C}$ and $\mathrm{H}-\mathrm{C}-\mathrm{O}$ bending at $\mathrm{C} 6$ (cellulose) & $898 w$ & $898 \mathrm{~m}$ \\
\hline bending of primary $\mathrm{C} 6-\mathrm{O}-\mathrm{S}$ & $815 \mathrm{~m}$ & $815 \mathrm{~m}$ \\
\hline
\end{tabular}

\subsection{Effect of Hs on Maize Plant Growth}

The effect of Hs application on maize plant growth is reported in Figure 3. Results indicated that LS5 was the most effective in promoting the leaf (Figure 3A) and root (Figure 3B) dry weight $(+140 \%$ and $+35 \%$, respectively), compared to the untreated plants. The remaining Hs did not substantially improve the leaf biomass produced by plants. However, they all stimulated the root growth appreciably. Specifically, LS3, LS4, and LH increased the root biomass of plants by $51 \%, 57 \%$ and $52 \%$, respectively, while LS2 and PH were by about $85 \%$, and LS1 was by $111 \%$.

A.

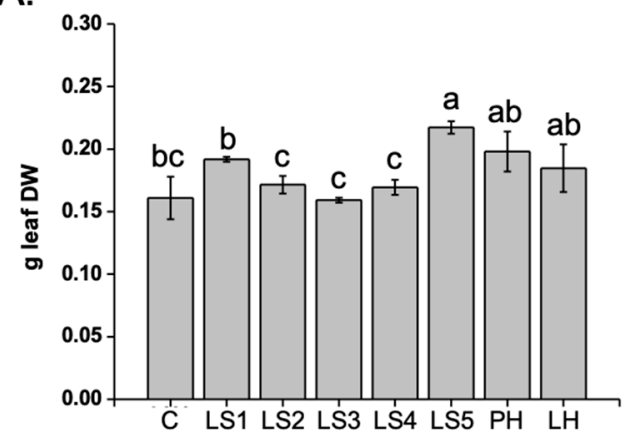

B.

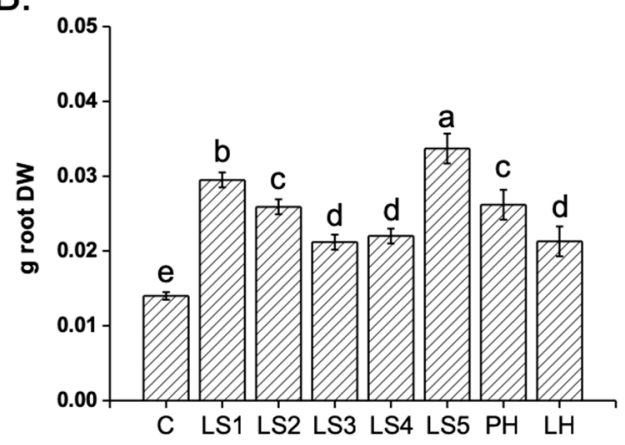

Figure 3. Effect of individual humates (Hs) on leaf (A) and root (B) dry weight of Z. mays L. plants. Twelve-day-old plants were supplied for two days with $\mathrm{Hs}$ at $1 \mathrm{mg} \mathrm{C} \mathrm{L}^{-1}$. Different letters above bars indicate significant differences at $p<0.05$, according to the Student-Newman-Keuls test. Data represent the means of three measurements with ten plants in each $( \pm \mathrm{SD}) . \mathrm{C}=$ control; $\mathrm{LH}=$ commercial lignosulfonate-based product; $\mathrm{PH}=$ commercial humate extracted from leonardite; LS1 - LS5 = specialty lignosulfonates.

\subsection{Effects of Hs on SPAD, RuBisCO activity, and N-compounds (Proteins and Phenolics)}

The effect of Hs on maize plants was additionally evaluated in terms of photosynthetic efficiency by measuring the SPAD index (Figure 4A) and the activity of the RuBisCO enzyme (Figure 4B). In general, $\mathrm{Hs}$ prompted the increase of the SPAD index values of plants to a similar extent (Figure $4 \mathrm{~A}$ ). 
Analogously, RuBisCO activity was increased by all Hs, but differences in the percent stimulation caused by individual Hs were observed in this case (Figure 4B). LS2, in particular, was the most effective in enhancing the activity of this enzyme (by about 70\%), followed by LS1, LS3, LS5, and PH (+30-50\%). The other Hs stimulated the RuBisCO activity to a lower extent.

A.

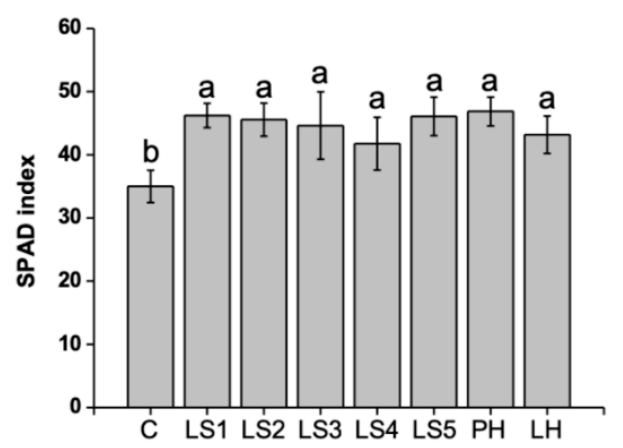

B.

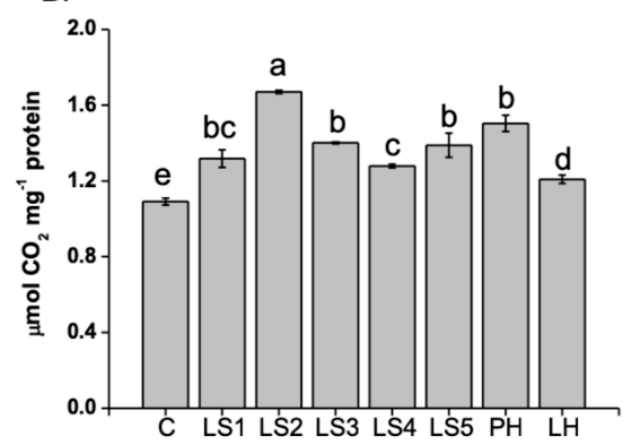

C.

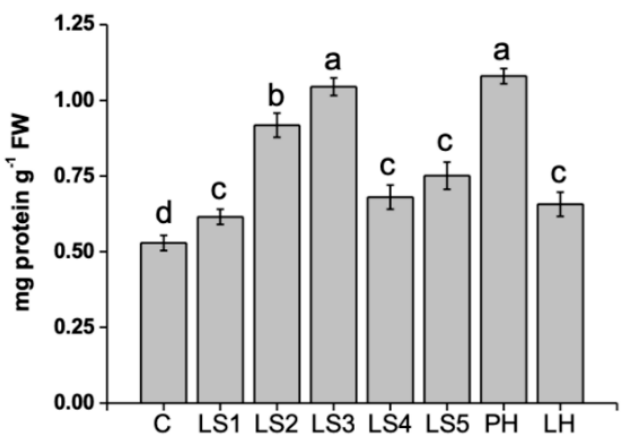

D.

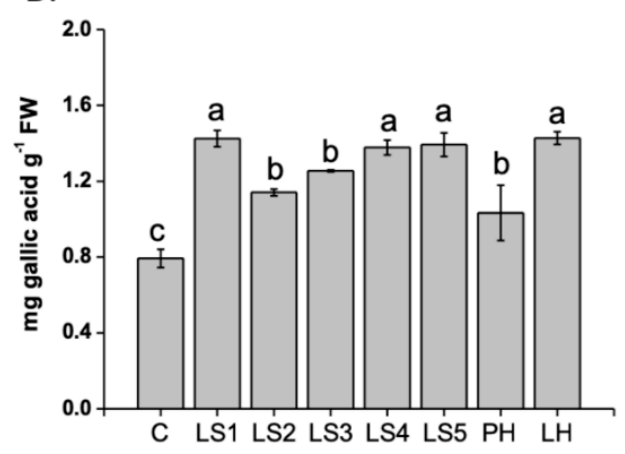

Figure 4. Effect of humates (Hs) on SPAD index (A), RuBisCO activity (B), protein content (C), and total phenolic compounds (D) in leaves of Z. mays L. plants. Twelve-day-old plants were supplied with $\mathrm{Hs}$ at $1 \mathrm{mg} \mathrm{C} \mathrm{L}^{-1}$ for two days. Different letters above bars indicate significant differences at $p<0.05$, according to Student-Newman-Keuls test. Data represent the means of three measurements with three plants in each $( \pm \mathrm{SD}) . \mathrm{C}=$ control; $\mathrm{LH}=$ commercial lignosulfonate-based product; $\mathrm{PH}=$ commercial humate extracted from leonardite; LS1-LS5= specialty lignosulfonates.

As the SPAD index is associated to the amount of $\mathrm{N}$ compounds in plants, the quantification of proteins, total phenols, and individual phenolic acids was performed. It is noteworthy that the content of total $\mathrm{N}$ was also measured in the plants (data not shown), but no significant differences were recorded, likely because of the limited duration of the experiment. Protein accumulation was enhanced in leaves of maize plants supplied with Hs (Figure 4C). LS2, LS3, and PH, in particular, induced the most pronounced increases $(+74 \%,+98 \%$, and $+104 \%$, respectively). The synthesis of phenol compounds (Figure 4D) was stimulated in leaves of maize plants treated with Hs as well. In this case, however, LS1, LH, LS4, and LS5 were responsible for the greatest increments (by about $80 \%$ ).

Differential accumulation of individual phenolic acids was also observed between maize plants supplied with Hs and the controls, as well as among plants treated with distinct Hs (Table 3). There were three derivatives of cinnamic acids (caffeic, $p$-coumaric, and ferulic acids), one ester of caffeic acid and (-)-quinic acid (chlorogenic acid), and one derivative of benzoic acid ( $p$-hydroxybenzoic acid). In most cases, Hs induced significantly higher accumulation of chlorogenic, caffeic, p-coumaric, ferulic, and p-hydroxybenzoic acids in leaves of maize plants compared to the controls. LS1, LS2, LS3, LS4, and LS5 especially, accounted for the most appreciable effects in this respect. Specifically, very high values of leaf phenolic acid accumulation were measured for chlorogenic and caffeic acids in plants treated with LS2 $(+168 \%$ and $184 \%$, respectively) and LS4 $(+651 \%$ and $262 \%$, respectively), for 
ferulic acid in plants provided with LS1 (+472\%), LS2 (328\%), LS3 (+222\%), and LS4 (+413\%), and for $p$-hydroxybenzoic acid in plants given with LS1 (+193\%), LS2 (+187\%), and LS4 (+202\%).

Table 3. Profile of phenolic compounds in leaves and roots of Z. mays L. Plants were grown for 12 days in a nutrient solution and supplied with individual humates at $1 \mathrm{mg} \mathrm{C} \mathrm{L}^{-1}$ for two days. $\mathrm{n}$. $\mathrm{d}$. = not detectable. Values along the same column following by different letters are statistically different at $p<0.05(n=3$, $\pm \mathrm{SD}$ ) according to Student-Newman-Keuls test. $\mathrm{C}=$ control; $\mathrm{LH}=$ commercial lignosulfonate-based product; $\mathrm{PH}=$ commercial humate extracted from leonardite; LS1-LS5= specialty lignosulfonates.

\begin{tabular}{|c|c|c|c|c|c|c|c|c|c|c|}
\hline & \multicolumn{2}{|c|}{ Chlorogenic } & \multicolumn{2}{|c|}{ Caffeic } & \multicolumn{2}{|c|}{$p$-Cumaric } & \multicolumn{2}{|c|}{ Ferulic } & \multicolumn{2}{|c|}{$p$-Hydroxybenzoic } \\
\hline & \multicolumn{10}{|c|}{ Leaves $\left(\mathrm{mg} \mathrm{k}^{-1} \mathrm{FW}\right)$} \\
\hline $\mathrm{C}$ & 30.29 & $\pm 4.11 \mathrm{e}$ & 0.52 & $\pm 0.02 \mathrm{~d}$ & 1.28 & $\pm 0.05 \mathrm{~d}$ & 0.58 & $\pm 0.02 c$ & 16.32 & $\pm 0.13 \mathrm{e}$ \\
\hline LS1 & 67.65 & $\pm 8.54 \mathrm{~b}$ & 1.41 & $\pm 0.02 \mathrm{c}$ & 3.02 & $\pm 0.05 a$ & 3.32 & $\pm 0.03 \mathrm{a}$ & 47.88 & $\pm 3.45 \mathrm{a}$ \\
\hline LS2 & 81.13 & $\pm 12.37 \mathrm{a}$ & 3.90 & $\pm 0.02 \mathrm{a}$ & 1.33 & $\pm 0.03 c$ & 2.48 & $\pm 0.06 \mathrm{a}$ & 46.88 & $\pm 5.33 \mathrm{a}$ \\
\hline LS3 & 51.24 & $\pm 6.32 \mathrm{c}$ & 1.34 & $\pm 0.05 \mathrm{c}$ & 2.61 & $\pm 0.06 \mathrm{~b}$ & 1.87 & $\pm 0.07 \mathrm{~b}$ & 30.04 & $\pm 7.34 \mathrm{c}$ \\
\hline LS4 & 85.98 & $\pm 7.10 \mathrm{a}$ & 1.88 & $\pm 0.05 \mathrm{~b}$ & 2.41 & $\pm 0.07 \mathrm{~b}$ & 4.13 & $\pm 0.05 a$ & 49.24 & $\pm 6.13 \mathrm{a}$ \\
\hline LS5 & 57.10 & $\pm 10.22 \mathrm{c}$ & 1.47 & $\pm 0.01 \mathrm{c}$ & 2.35 & $\pm 0.05 b$ & 1.24 & $\pm 0.05 b$ & 39.94 & $\pm 5.28 b$ \\
\hline PH & 34.09 & $\pm 5.13 \mathrm{~d}$ & 0.72 & $\pm 0.02 \mathrm{~d}$ & 3.09 & $\pm 0.07 \mathrm{a}$ & 1.22 & $\pm 0.05 \mathrm{~b}$ & 40.69 & $\pm 6.13 \mathrm{~b}$ \\
\hline \multirow[t]{2}{*}{ LH } & 37.48 & $\pm 5.08 \mathrm{~d}$ & 0.92 & $\pm 0.03 \mathrm{~d}$ & 2.03 & $\pm 0.03 c$ & 0.72 & $\pm 0.03 c$ & 24.78 & $\pm 5.13 \mathrm{~d}$ \\
\hline & \multicolumn{10}{|c|}{ Roots $\left(\mathrm{mg} \mathrm{kg}^{-1} \mathrm{FW}\right)$} \\
\hline $\mathrm{C}$ & 3.54 & $\pm 0.12 c$ & & d. & 5.71 & $\pm 0.30 \mathrm{~b}$ & 0.58 & $\pm 0.01 \mathrm{c}$ & 29.97 & $\pm 4.14 \mathrm{a}$ \\
\hline LS1 & 3.56 & $\pm 0.11 c$ & & d. & 1.04 & $\pm 0.62 c$ & 3.09 & $\pm 0.03 \mathrm{a}$ & 3.65 & $\pm 0.84 \mathrm{~d}$ \\
\hline LS2 & 6.05 & $\pm 0.13 \mathrm{a}$ & & d. & 3.16 & $\pm 0.61 b$ & 2.86 & $\pm 0.05 a$ & 11.57 & $\pm 3.12 \mathrm{c}$ \\
\hline LS3 & 3.44 & $\pm 0.12 c$ & & & 6.29 & $\pm 0.82 \mathrm{a}$ & 0.85 & $\pm 0.03 c$ & 21.07 & $\pm 2.34 b$ \\
\hline LS4 & 5.67 & $\pm 0.23 b$ & & & 5.10 & $\pm 0.72 b$ & 1.12 & $\pm 0.03 \mathrm{~b}$ & 19.46 & $\pm 4.13 \mathrm{~b}$ \\
\hline LS5 & 7.61 & $\pm 0.14 \mathrm{a}$ & & d. & 4.89 & $\pm 0.53 b$ & 1.69 & $\pm 0.05 \mathrm{~b}$ & 24.39 & $\pm 6.81 b$ \\
\hline PH & 7.54 & $\pm 0.17 \mathrm{a}$ & & d. & 6.46 & $\pm 0.52 \mathrm{a}$ & 2.65 & $\pm 0.05 \mathrm{a}$ & 31.12 & $\pm 5.68 \mathrm{a}$ \\
\hline LH & 3.48 & $\pm 0.18 \mathrm{c}$ & & d. & 6.15 & $\pm 0.51 \mathrm{a}$ & 0.75 & $\pm 0.01 \mathrm{c}$ & 20.29 & $\pm 3.12 b$ \\
\hline
\end{tabular}

In roots, only chlorogenic and ferulic acids were more accumulated in plants treated with Hs than the controls. The highest values of chlorogenic acid content were observed in roots after plant treatment with LS2 $(+71 \%)$, LS4 $(+60 \%)$, LS5 $(+115 \%)$, PH $(+113 \%)$. With respect to ferulic acid, maximum accumulation was measured in roots of plants supplied with LS1 $(+436 \%)$, LS2 (+396\%), and $\mathrm{PH}(+361 \%)$.

\subsection{Effects of Hs on GS and GOGAT Activities}

Further effects of Hs on maize plant metabolism were investigated by measuring the activities of two enzymes (GS and GOGAT) that catalyze key steps in N assimilation (Figure 5). Overall, a greater activity of such enzymes was determined in plants supplied with Hs. The activity of GS in leaves in particular, was increased by LH (+44\%), LS4 (+24\%), and LS5 (+18\%) (Figure 5A), while the activity of GOGAT was stimulated by all Hs applied to plants (Figure 5B). LS3 accounted for the maximum leaf activity of GOGAT (+98\%). In roots, the activity of both GS and GOGAT enzymes was enhanced by all Hs (Figure 5C,D). In the case of GS, the highest activity was detected in roots of plants treated with LS2 (Figure 5C), while maximum GOGAT activity was measured in plants supplied with LS1 and LS5 (Figure 5D). 
A.

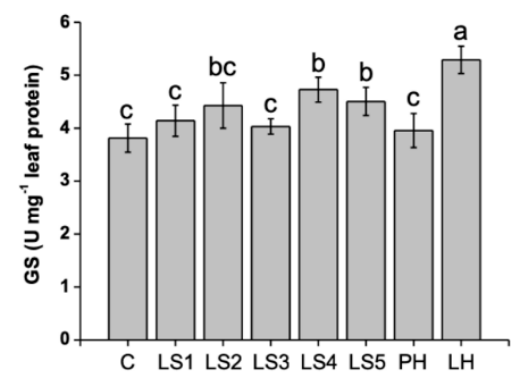

B.

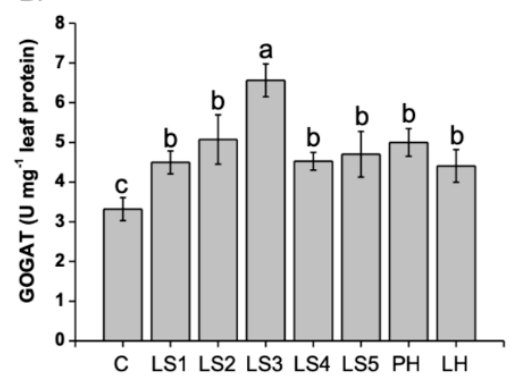

C.

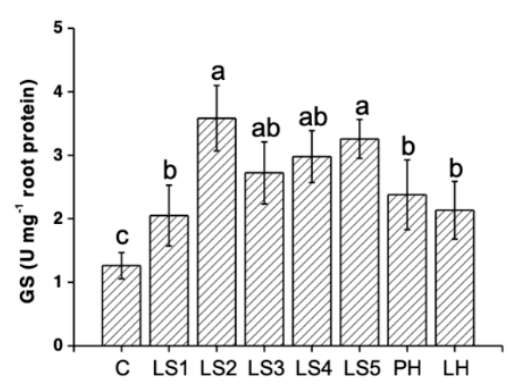

D.

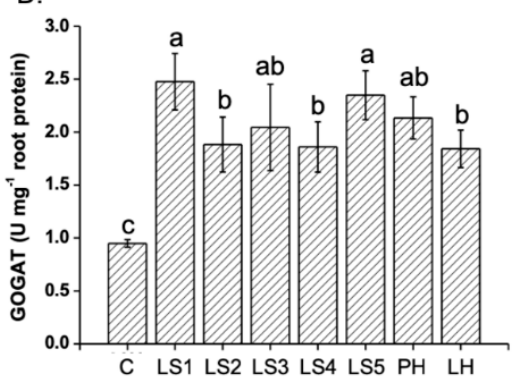

Figure 5. Effect of humates (Hs) on glutamine synthetase (GS) and glutamate synthase (GOGAT) activity in leaves (A, B, respectively) and roots (C, D, respectively) of Z. mays L. plants. Twelve-day-old plants were supplied with $\mathrm{Hs}$ at $1 \mathrm{mg} \mathrm{C} \mathrm{L}^{-1}$ for two days. Different letters above bars indicate significant differences at $p<0.05$, according to the Student-Newman-Keuls test. Data represent the means of three measurements with three plants in each $( \pm \mathrm{SD}) . \mathrm{C}=$ control; $\mathrm{LH}=$ commercial lignosulfonate-based product; $\mathrm{PH}=$ commercial humate extracted from leonardite; LS1 - LS5 = specialty lignosulfonates.

\subsection{Effects of Hs on Reducing Sugar Accumulation}

The content of soluble reducing sugars (glucose and fructose) was increased in leaves of plants treated with Hs (Figure 6). Precisely, improved glucose accumulation was observed in leaves of maize plants after treatment with LS1, LS2, and LH $(+39 \%,+58 \%,+41 \%$, respectively, Figure $6 \mathrm{~A})$. With respect to fructose, all $\mathrm{Hs}$ stimulate its accumulation, with maximum values determined by LS2 and LS3 (+92\% and $+111 \%$, respectively, Figure $6 \mathrm{~A})$. In roots, an opposite trend was evident, as the content of both sugars decreased when plants were treated with Hs, with few exceptions (Figure 6B).

A.

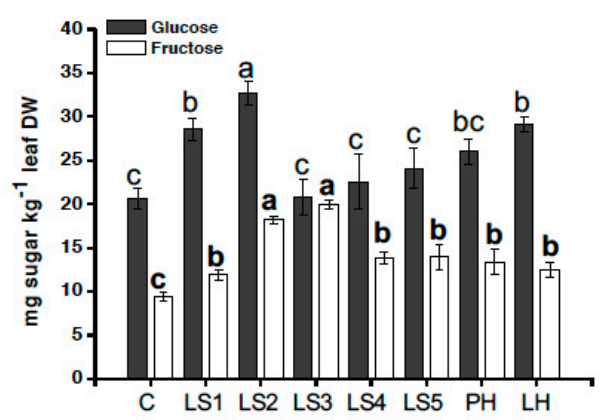

B.

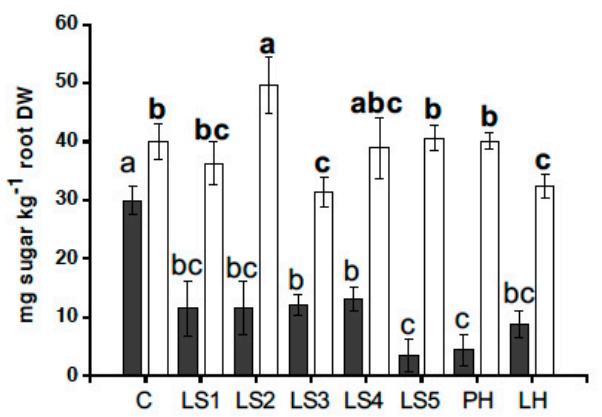

Figure 6. Effect of individual humates (Hs) on glucose and fructose accumulation in leaves (A) and roots (B) of Z. mays L. plants. Twelve-day-old plants were supplied with Hs at $1 \mathrm{mg} \mathrm{C} \mathrm{L}^{-1}$ for two days. Different letters above bars (un-bolded for glucose and bolded for fructose) indicate significant differences at $p<0.05$, according to the Student-Newman-Keuls test. Data represent the means of three measurements with three plants in each $( \pm \mathrm{SD})$. $\mathrm{C}=$ control; $\mathrm{LH}=$ commercial lignosulfonate-based product; $\mathrm{PH}=$ commercial humate extracted from leonardite; LS1 - LS5 = specialty lignosulfonates. 


\subsection{Statistical Analysis of Data}

The correlation analysis evidenced significant relationships between the parameters analyzed in maize plants subjected to treatment with Hs (Table S1). The root dry weight, which was more stimulated than the leaf dry weight by Hs, positively correlated with SPAD, total phenols, GS and GOGAT root activity, and RubisCO activity, whereas it negatively correlated with the content of glucose in roots. SPAD index values displayed a positive correlation with the content of $\mathrm{N}$ metabolites (proteins and phenols), the activity of GOGAT, GS (only in roots), RubisCO, and the leaf fructose content. However, SPAD negatively correlated with the root glucose content. Total phenols showed positive correlation with GS activity in leaves and roots and GOGAT activity in roots. The activity of GS in leaves did not show any correlation with the other parameters analyzed, but GS activity in roots positively correlated with the activity of GOGAT in leaves and roots. The activity of both $\mathrm{N}$ enzymes also positively correlated with RubisCO activity. The activity of all three enzymes, GS (in roots), GOGAT, and RubisCO, negatively correlated with glucose content in roots. RuBisCO positively correlated with the leaf glucose content and fructose content in both leaves and roots, whereas it negatively correlated with the root glucose.

With respect to PCA analysis, three factors accounted for $91 \%$ of the total variance. Factor 1 explained $53.6 \%$ of the variance and positively correlated with GS and GOGAT activity in roots, SPAD, total phenols, while it negatively correlated with glucose content in roots. Factor 2 explained $22.7 \%$ of the variance and was positively correlated with GOGAT activity in leaves, protein content, and leaf fructose amount. Factor 3 explained the remaining $14.8 \%$ of the variance and was correlated with the content of fructose in roots and GS activity in leaves. Plotting data reported in Table S2 according to PC1 and PC2 allowed three clusters to be identified (Figure S1A,C); a main group constituted by plants $1,2,3,4,5,6$, and 7, corresponding to LS1, LS2, LS4, LS5, PH, and LH, and the other two by control (untreated, 8) and LS3 (3). In particular, LS1, LS2, LS4, LS5, PH, and LH were characterized by high values of GS and GOGAT activity in roots, SPAD, and total phenols, whilst LS3 had high values of GOGAT activity in roots and protein. The control plants had higher values of glucose content in roots. Plotting PC1 and PC2 also revealed that, among plants treated with humates LS1, LS2, LS4, LS5, PH and $\mathrm{LH}$, those treated with $\mathrm{LH}$ tended to be at the bottom of the cloud, and $\mathrm{PH}$ was at the top, along the axis 2. It should be also noted that plotting PC1 and PC3, LH (7) differed from the other treatments for high GOGAT activity in leaves.

\section{Discussion}

Humates can differ in composition depending on the source material and process type employed for their production. Therefore, they can show significant variation in biostimulant properties. In this study, we assayed seven humates (a commercial lignosulfonate-based product, a commercial humate extracted from leonardite, and five specialty lignosulfonates provided by Borregaard's company) by determining their elemental content and dissecting the major functional groups occurring in their formulation. Then, in order to determine the plant-growth promoting potential of Hs, we evaluated differences in their capacity to promote plant biomass production, $\mathrm{N}$ assimilation into organic compounds (chlorophylls, proteins and phenols), and photosynthesis.

We found that all products were able to stimulate plant growth and the metabolic responses typically triggered by biostimulants. Therefore, untreated plants were different from plants treated with tested Hs in terms of performance, as revealed by PCA analysis. However, LS1, LS2, LS3, and LS5 appeared to be the most effective in this respect, being able to induce the greatest increments (up to 184\%) of most physiological parameters (dry weight, root GS activity, GOGAT activity, RuBisCO activity) and targeted-biochemical markers (SPAD, proteins, phenols, fructose content) in maize, compared to the untreated plants. A general overview of such increments is depicted in the heat map of plant-associated parameters influenced by individual humates, reported in Figure S2. LS2 and LS3 contained a similar percent content of total C and N, as well as LS1 and LS5. The spectroscopic characteristic of all samples and especially LS2 and LS5 revealed the presence of cellulose residues and 
aromatic groups. LS4 and PH contained the highest percentage in aromatic groups according to the deconvolution process of FT-IR spectra, while for LS1 the functional group distribution appeared to be a mixture of the same groups observed in LS4 and $\mathrm{PH}$, but with a considerable hydrophilic feature (see the band at $1632 \mathrm{~cm}^{-1}$ ). Therefore, the $\mathrm{C}$ and $\mathrm{N}$ composition and profile in functional groups of specialty products LS1, LS2, LS3, and LS5 could explain their better efficiency as biostimulants compared to the lignosulfonate LH.

Overall, root growth was more stimulated (+51-140\%) than leaf growth by all Hs $(+5-35 \%)$, with more pronounced effects observed in plants treated with LS1 and LS5. These results are in line with the current literature that reports early root growth as a typical response of plants treated with humic substances, while the stimulation of leaf growth is generally recognized as a delayed response $[10,17,39]$. One possible explanation of this effect is that humic substances can act on root development by influencing the hormonal balance within the plants and nitric oxide distribution, either directly or indirectly, and by modifying the nutrient uptake by plants and the activity of root membrane $\mathrm{H}^{+}$-ATPase $[8,39,40]$. Early root development could also be ascribed to the biological properties of humic substances, whose hormone-like activity has been previously described [41,42], and that Hs tested in this study might possess as well. Ertani et al. [17], in particular, reported the auxin-like and gibberellin-like activity of two lignosulfonates, and the gibberellin-like activity of a leonardite humic acid. The hormone-like activity of humic substances and commercial humates are likely due to their content in auxin-like substances, as well as to the presence of phenol-C groups with biological activity $[43,44]$.

Hs were also effective in promoting N metabolism. In particular, LS1, LS2, and LS5 determined the highest increases in the activity of $\mathrm{N}$ assimilation enzymes, i.e., glutamine synthetase (GS) and glutamate synthase (GOGAT), in roots. This finding could explain why plants treated with these products developed their roots more. In this respect, the root dry weight of maize plants positively correlated with GS and GOGAT root activity. In general, all Hs enhanced the activity of GS and GOGAT more in roots than in leaves, which may suggest that early root growth stimulation in maize by Hs was also a result of a more pronounced $\mathrm{N}$ metabolism enhancement and decreased $\mathrm{N}$ storage. Similar findings and hypothesis have been previously reported by Jannin et al. [45]. Higher activity of $\mathrm{N}$ enzymes in roots might be due to metabolic changes related to differences in the root/shoot nitrate balance occurring under LH treatment [39]. In leaves, GOGAT activity was significantly stimulated by all Hs, while GS activity was stimulated by only four of them. Such differences could be ascribed to distinct mechanisms of regulation of $\mathrm{N}$ enzymes induced by several factors, including $\mathrm{N}$ metabolites (e.g., ammonium, glutamine, and glutamate) that are known to exert feedback effects [46-48]. In this respect, those Hs determining the highest increases in leaf protein accumulation were responsible for the least increases in GS leaf activity. Interestingly, they also stimulated the accumulation of phenolic compounds as the other Hs, but to a less extent. This observation seems to suggest that when plants are treated with $\mathrm{Hs}$, two preferential metabolic pathways can be mainly stimulated, i.e., the $\mathrm{N}$ primary metabolism that produces proteins and the secondary metabolism involved in the synthesis of phenolics. These two metabolic pathways have been previously identified as principal targets of humic substances and other biostimulants, including lignosulfonate-humates, in maize and other plant species [17,49]. With respect to phenolic compounds, the increase in content of a number of them, especially in leaves, to levels that were not injurious to plants, can be deemed as an important result because these phytochemicals have recognized health beneficial properties, are implied in the plant defense responses against stress conditions, and mediate plant relationships with ecological partners [50-53].

The positive effects of all $\mathrm{Hs}$ on plant metabolism was also confirmed by the increased activity of RuBisCO, i.e., the enzyme responsible for $\mathrm{CO}_{2}$ fixation in the Calvin cycle. Indeed, measuring the RuBisCO activity allowed for knowing whether Hs stimulated the photosynthetic efficiency of plants, because higher activity generally corresponds to higher photosynthetic rates and productivity. The increased activity of RuBisCO in plants under treatment by humic substances could be due to 
increased number of chloroplasts per cell, as proposed by Jannin et al. [45]. RuBisCO activity positively correlated with the SPAD index values and the leaf content of reducing sugars. Similar results were previously reported by Ertani et al. [17].

In our study, we observed a reduction in glucose and fructose accumulation in roots of maize plants. Glucose is mainly produced in the cytosol from triose-phosphate precursors produced during the Calvin cycle and its accumulation in cells is influenced by different factors, like the photosynthetic rate, the need of glucose for energy-dependent processes, and the metabolic fate of the precursor glutaraldehyde 3-P (including the synthesis of starch). In roots, the level of carbohydrates depends on the source of $\mathrm{N}$ they receive $\left(\mathrm{NO}_{3}, \mathrm{NH}_{4}\right.$, or amino acids), the rate of transport of photosynthates and the quantity of reserves that are stored in the root tissues. The different distribution of glucose between leaves and roots also depends on the need of the plant to use glucose in a specific organ for a metabolic requirement. The decrease of glucose in the roots, for instance, may be indicative of a high demand for ATP-dependent nutrient transport and other energy-requiring processes in the root cells, including growth processes, and could be associated with the increased need of C-skeleton for the synthesis of $\mathrm{N}$ compounds. A similar reasoning can be made for fructose.

\section{Materials and Methods}

\subsection{Elemental Composition and Spectroscopic Analysis of Hs}

Seven humates $(\mathrm{Hs})$ were tested in this study for their biostimulant properties. All these products completely dissolved in $\mathrm{H}_{2} \mathrm{O}$ without leaving insoluble clumps. The carbon (C), nitrogen $(\mathrm{N})$, and sulfur (S) contents of Hs were determined via dry combustion conducted in the element analyzer vario MACRO CNS (Hanau, Germany).

The Fourier transform infrared (FTIR) spectra of these products were recorded using an ALPHA FTIR spectrometer (Bruker Optics, Ettlingen, Germany) equipped with an ATR (attenuated total reflectance) sampling device containing diamond crystals. The absorbance spectra were recorded between $4000 \mathrm{~cm}^{-1}$ and $400 \mathrm{~cm}^{-1}$, at a spectral resolution of $4 \mathrm{~cm}^{-1}$, with 64 scans co-added and averaged. A background spectrum of air was recorded under the same procedure conditions before each series of measurements. Spectra were processed with the Grams/386 spectroscopic software (version 6.00, Galactic Industries Corporation, Salem, NH). Overlapping peaks were resolved using a peak fitting analysis in the spectral region from 1800 to $1000 \mathrm{~cm}^{-1}$ by using the Grams/386 spectroscopic software (version 6.00, Galactic Industries Corporation, Salem, NH). The overlapping bands were resolved with a Gaussian function. The best fitting parameters were determined by minimization of the reduced Chi square $\left(\chi^{2}\right)$. Good agreement between experimental and calculated profiles was obtained, with coefficients of determination, $\mathrm{R}^{2}$, ranging from 0.999 to 0.988 and the standard error, $\mathrm{SE}$, from 0.001 to 0.003 . All data are expressed as percentage area.

FT-Raman spectra of Hs were recorded in solid state with a Multiram FT-Raman spectrometer (Bruker Optics, Ettlingen, Germany) equipped with a cooled Ge-diode detector. The excitation source was a Nd-YAG laser (1.064 nm, about $30 \mathrm{~mW}$ laser power on the sample) in the backscattering $\left(180^{\circ}\right)$ configuration. The low laser power was due to the brown color of the samples, which burned out using a higher laser power. As a consequence of burning, it was possible to record only the spectra of LS2 and LS5.

\subsection{Plant Material and Experimental Design}

Seeds of Zea mays L. (P1921, Pioneer HI-BRED, Italia Sementi S.r.l.) were soaked in distilled water overnight and then surface-sterilized in $5 \%(\mathrm{v} / \mathrm{v})$ sodium hypochlorite for $10 \mathrm{~min}$ while shaking. Seeds were germinated on filter paper wetted with distilled water for $60 \mathrm{~h}$ in the dark at $25^{\circ} \mathrm{C}$. Seedlings were then transferred into $3 \mathrm{~L}$ pots in the presence of a thoroughly aerated Hoagland solution, with a density of 24 plants per pot. The nutrient solution was renewed every $48 \mathrm{~h}$ and contained the following salts $(\mu \mathrm{M}): \mathrm{KH}_{2} \mathrm{PO}_{4}(40), \mathrm{Ca}\left(\mathrm{NO}_{3}\right)_{2}(200), \mathrm{KNO}_{3}(200), \mathrm{MgSO}_{4}(200)$, FeNaEDTA (10), $\mathrm{H}_{3} \mathrm{BO}_{3}$ (4.6), 
$\mathrm{CuCl}_{2} \cdot 2 \mathrm{H}_{2} \mathrm{O}(0.036), \mathrm{MnCl}_{2} \cdot 4 \mathrm{H}_{2} \mathrm{O}(0.9), \mathrm{ZnCl}_{2}$ (0.09), and $\mathrm{NaMoO} \cdot 2 \mathrm{H}_{2} \mathrm{O}(0.01)$. Plants were grown inside a chamber with $14 \mathrm{~h}$ of light per day, in air temperatures of $21^{\circ} \mathrm{C}$ (night) and $27^{\circ} \mathrm{C}$ (day), at a relative humidity of $70 / 85 \%$, and with a photon flux density of $280 \mathrm{~mol} \mathrm{~m}^{-2} \mathrm{~s}^{-1}$. After twelve days of growth in hydroponics, each Hs was added in a unique application to the nutrient solution at $1 \mathrm{mg} \mathrm{C} \mathrm{L}^{-1}$ (for each treatment with single $\mathrm{Hs}, 3$ pots were prepared). After $48 \mathrm{~h}$ from the addition of $\mathrm{Hs}$, plants were harvested. The choice of this short incubation time was dictated by results obtained in several previous studies, where a period of $24-48 \mathrm{~h}$ was found to induce early molecular responses and morpho-physiological changes in both roots and leaves. Plants that were not added with Hs served as controls ( 3 pots, 24 plants per pot).

At the end of the treatment, plants were randomly harvested and then carefully washed and dried with blotting paper. A sub-sample of the plant material was immediately frozen with liquid nitrogen and kept at $-80{ }^{\circ} \mathrm{C}$, to be used for biochemical analyses. For dry weight measurement, 10 plants randomly harvested were used (ten per treatment from each pot). The samples were placed in a drying oven for $2 \mathrm{~d}$ at $70{ }^{\circ} \mathrm{C}$ and allowed to cool for $2 \mathrm{~h}$ inside a closed bell jar. The dry weight of individual roots and leaves was measured for each plant.

\subsection{Determination of the SPAD Index}

The relative chlorophyll content was determined using a non-destructive method that employed light transmission across a leaf, at two wavelengths, to quantify the greenness and thickness of leaves. The ratio of the transmission of the two wavelengths provides a chlorophyll content index that is also named the SPAD index. The analyses were performed using a SPAD (Soil Plant Analysis Development) chlorophyll meter (SPAD-502 model, Minolta Camera Co, Ltd., Osaka, Japan) and the SPAD index was measured on the last expanded leaf of maize plants. The determination was carried out on 5 measurements per leaf from 10 plants per each treatment.

\subsection{Analysis of Soluble Proteins and Reducing Sugars}

For protein extraction, frozen foliar tissues $(100 \mathrm{mg})$ of five plants per pot were ground in liquid nitrogen and vortexed in the presence of $5 \mathrm{~mL}$ buffer $(100 \mathrm{mM}$ Tris- $\mathrm{HCl} \mathrm{pH} \mathrm{7.5,} 1 \mathrm{mM} \mathrm{Na} 2$ EDTA, $5 \mathrm{mM}$ DTT) and centrifuged at $14,000 \mathrm{~g}$. The supernatants were mixed with $10 \%(\mathrm{w} / \mathrm{v})$ trichloroacetic acid and then centrifuged. The pellets were finally re-suspended in $0.1 \mathrm{~N} \mathrm{NaOH}$. The protein concentration was determined using the Bradford method through a UV/VIS spectrophotometer (Lambda 1, Perkin-Elmer, Monza, Italy) at $\lambda=595 \mathrm{~nm}$. Protein concentration was expressed as $\mathrm{mg}$ of protein $\mathrm{g}^{-1}$ fresh weight $(\mathrm{FW})$.

For reducing sugar analysis, foliar tissues $(100 \mathrm{mg})$ of five plants per pot were dried for $48 \mathrm{~h}$ at $80{ }^{\circ} \mathrm{C}$, ground to obtain a fine powder, and then extracted with $2.5 \mathrm{~mL} 0.1 \mathrm{~N} \mathrm{H}_{2} \mathrm{SO}_{4}$. Samples were incubated in a heating block for $40 \mathrm{~min}$ at $60^{\circ} \mathrm{C}$ and then centrifuged at $6000 \mathrm{~g}$ for $10 \mathrm{~min}$ at $4{ }^{\circ} \mathrm{C}$. Supernatants were filtrated $\left(0.2 \mu \mathrm{m}\right.$, Membra-Fil ${ }^{\circledR}$ Whatman Brand, Whatman, Milan, Italy) and further analyzed via HPLC (Perkin Elmer 410). Soluble sugars were separated using a Biorad Aminex $87 \mathrm{C}$ column $(300 \times 7.8 \mathrm{~mm})$ with $\mathrm{H}_{2} \mathrm{O}$ as eluent at a flow rate of $0.6 \mathrm{~mL} \mathrm{~min}^{-1}$. Sugar concentration was expressed as $\mathrm{mg} \mathrm{g}^{-1}$ dry weight (DW).

\subsection{Analysis of Total and Individual Phenolic Compounds}

The content of total phenols in plant samples was quantified using the Folin-Ciocalteu method. For individual phenol detection, extraction from frozen plant material of five plants $(1$ plant $=$ 1 biological replicate) was performed using water/methanol (1:1 v/v), filtered at $0.45 \mu \mathrm{m}$. Phenols were separated via an HPLC 2700 (Thermo Finnigan, San Jose, CA, USA) coupled with an 1806 UV/Vis (Thermo Finnigan, San Jose, CA, USA) detector. The column was a TM-LC 18 (Supelcosil) equipped with pre-column TM-LC 18 (Pelliguard, Supelco). Elution was conducted at a flow rate of $1.2 \mathrm{~mL} \mathrm{~min}{ }^{-1}$ using a mixture of water/ n-butanol/ acetic acid (80.5:18:1.5 v/v) as the mobile phase. The injection volume of each sample was $20 \mu \mathrm{L}$. Detection was performed at $\lambda=275 \mathrm{~nm}$ and the identification of compounds was obtained by comparison of their retention time values with those of corresponding 
standards. The calibration curve and quantification were performed considering the relationship between peak areas vs. standard concentrations at four concentrations $(n=4)$. A linear fitting with an $\mathrm{R}$ squared value of $\left(R^{2}\right)=0.99$ was obtained.

\subsection{Determination of GS, GOGAT and RuBisCO Activity}

For the assay of glutamine synthetase (GS) and glutamate synthase (GOGAT) enzyme activity, fresh root and leaf tissues $(1 \mathrm{~g})$ were ground in a mortar with $10 \mathrm{~mL}$ of $100 \mathrm{mM}$ Hepes-NaOH solution at $\mathrm{pH} 7.5,5 \mathrm{mM} \mathrm{MgCl}_{2}$ solution, and $1 \mathrm{mM}$ dithiothreitol. For the RuBisCO enzyme, the extraction protocol was the same as for GS and GOGAT, but the enzyme activity in this case was measured in leaves only and the ratio of plant material to buffer was 1:3 (w/v). The extracts were filtered through two layers of muslin and centrifuged at $20,000 \mathrm{~g}$ for $15 \mathrm{~min}$ at $4{ }^{\circ} \mathrm{C}$. The supernatants were used for enzymatic assays.

For the glutamine synthetase (GS EC 6.3.1.2) assay, each mixture contained $90 \mathrm{mM}$ imidazole- $\mathrm{HCl}$ (pH 7.0), $60 \mathrm{mM}$ hydroxylamine (neutralized), $20 \mathrm{mM} \mathrm{KAsO}_{4}, 3 \mathrm{mM} \mathrm{MnCl}_{2}, 0.4 \mathrm{mM}$ ADP, $120 \mathrm{mM}$ glutamine, and enzyme extract. The assay was performed in a final volume of $750 \mu \mathrm{L}$. The enzymatic reaction was developed for $15 \mathrm{~min}$ at $37^{\circ} \mathrm{C}$. The $\alpha$-glutamyl hydroxamate was colorimetrically determined by addition of $250 \mu \mathrm{L}$ of a mixture (1:1:1) of $10 \%$ (w/v) $\mathrm{FeCl}_{3} \cdot 6 \mathrm{H}_{2} \mathrm{O}$ in $0.2 \mathrm{M} \mathrm{HCl}, 24 \%$ (w/v) trichloroacetic acid and $50 \%(\mathrm{w} / \mathrm{v}) \mathrm{HCl}$. The optical density was measured at $\lambda=540 \mathrm{~nm}$. Enzyme activity was expressed in $\mu \mathrm{mol}^{-1} \mathrm{~g}^{-1} \mathrm{FW}$, representing the amount of enzyme catalyzing the formation of 1 nmole $\gamma$-glutamyl-hydroxamate $\mathrm{min}^{-1}$.

The glutamate synthase (GOGAT EC 1.4.7.1) assay contained $25 \mathrm{mM}$ Hepes-NaOH (pH 7.5), $2 \mathrm{mM}$ L glutamine, $1 \mathrm{mM} \alpha$-ketoglutaric acid, $0.1 \mathrm{mM} \mathrm{NADH}, 1 \mathrm{mM} \mathrm{Na}{ }_{2}$ EDTA, and $100 \mu \mathrm{L}$ of enzyme extract. GOGAT activity was measured spectrophotometrically by monitoring NADH oxidation at $\lambda=340 \mathrm{~nm}$. The enzyme activity was expressed in $\mu \mathrm{mol}^{-1} \mathrm{~g}^{-1} \mathrm{FW}$, representing the amount of enzyme catalyzing the oxidation of 1 nmole NADH $\mathrm{min}^{-1}$.

The activity of RuBisCO (EC 4.1.1.39) was determined spectrophotometrically in a coupled assay by measuring the production of 3-phosphoglycerate following a 5 min period of incubation with $2 \mathrm{~mL}$ of $10 \mathrm{mM} \mathrm{MgCl}_{2}$ and $20 \mathrm{mM} \mathrm{NaHCO}_{3}$ [54].

For each enzyme activity assay, analyses were conducted in three biological replicates ( 1 plant $=$ 1 biological replicate) per treatment and the absorbance in the samples was measured using a JASCO V-530 UV/VIS spectrophotometer.

\subsection{Statistical Analysis}

For all determinations, the analysis of variance (ANOVA) was performed using the SPSS software version 19.0 (SPSS Inc. 1999), which was followed by pair-wise post hoc analyses (Student-Newman-Keuls test) to determine which means differed significantly at $p<0.05( \pm \mathrm{SD})$. The number of biological replicates varied depending on the analysis performed and is indicated in the figure and table legends. Correlations between variables were determined using Pearson's coefficient. To identify the structure of the interdependences between the main parameters, a joint principal component analysis (PCA) was performed on the following variables, considering both untreated plants (control) and plants treated with the different humates: Root dry weight, leaf dry weight, SPAD, proteins, total phenols, leaf GS, root GS, leaf GOGAT, root GOGAT, RuBisCO, leaf glucose, leaf fructose, root glucose, and root glucose. The standardized variables were subjected to PCA. Rotated orthogonal components (varimax method of rotation) were extracted and the relative scores were determined. Only PCs with an eigenvalue $>1$ were considered for the discussion. Statistics were performed using SPSS software version 25.0 (SPSS, Chicago, IL).

\section{Conclusions}

In conclusion, the current study provides clear evidence that all tested products acted as biostimulants. Additionally, the specialty lignosulfonates provided by Borregaard's company were 
apparently the most effective in this role, likely because of the novel process employed for their production and the products' chemical features (e.g., different $C$ content values and presence of functional groups). These results support the importance of setting up new technologies and advanced industrial processes for the production of novel commercial humates and lignosulfonates with better formulation performance, which can be used as efficient biostimulants during crop cultivation in the framework of sustainable agriculture. Future studies could be performed in field trials and using other crop species, including horticultural crops, to definitely confirm the positive characteristics of these products under varying and/or stress conditions.

Supplementary Materials: The following are available online at http://www.mdpi.com/2073-4395/9/8/445/s1, Table S1: Correlations between variables determined using Pearson's coefficient. Asterisks indicate significant correlation at $p<0.05\left(^{*}\right)$ or $p<0.01\left(^{* *}\right) . \mathrm{r}=$ root, $1=$ leaf, $\mathrm{dw}=$ dry weight, TP = total phenols, GS = glutamine synthetase, $\mathrm{GOGAT}=$ glutamate synthase, $\mathrm{FRU}=$ fructose, $\mathrm{GLU}=$ glucose, $\mathrm{PROT}=$ proteins, Table S2: Loadings values of the plant variables on the axes identified by principal components (PC) analysis for the different types of treatment and control. $\mathrm{r}=$ root, $\mathrm{l}=$ leaf, $\mathrm{dw}=$ dry weight, $\mathrm{TP}=$ total phenols, $\mathrm{GS}=$ glutamine synthetase, GOGAT $=$ glutamate synthase, $\mathrm{FRU}=$ fructose, $\mathrm{GLU}=$ glucose, $\mathrm{PROT}=$ proteins. Figure S1: Position of the treated and untreated plants $(1=\mathrm{LS} 1,2=\mathrm{LS} 2,3=\mathrm{LS} 3,4=\mathrm{LS} 4,5=\mathrm{LS} 5,6=\mathrm{PH}, 7=\mathrm{LH}$, and $8=$ control $)$ in the reduced space of the first two principal components (PC1 and PC2) (A) and on PC1 and PC3 (B); variables projected in the plane determined by PC1 and PC2 (D) and PC1 and PC3 (C). r = root, $1=$ leaf, $d w=$ dry weight, $\mathrm{TP}=$ total phenols, GS = glutamine synthetase, GOGAT = glutamate synthase, $\mathrm{FRU}=$ fructose, $\mathrm{GLU}=$ glucose, PROT = proteins, Figure S2: Heat map of plant-associated parameters influenced by individual humates. Different colors indicate different levels of induction/repression (more red more repression, more blue more induction). $\mathrm{r}=$ root, $\mathrm{l}=$ leaf, $\mathrm{dw}=$ dry weight, $\mathrm{TP}=$ total phenols, $\mathrm{GS}=$ glutamine synthetase, GOGAT = glutamate synthase, $\mathrm{FRU}=$ fructose, $\mathrm{GLU}=$ glucose, $\mathrm{PROT}=$ protein .

Author Contributions: O.F. and A.T. performed the spectroscopic analysis and wrote the relative part in the ms; A.E. performed the physiological analyses, bioassays and chemical analyses of the products and wrote the ms; M.S. wrote the ms; D.P. critically read the ms and performed the statistical analyses of data; S.N. designed the study. All the authors critically reviewed the ms.

Funding: This study was funded by Borregaard (Hjalmar Wessels vei, Sarpsborg, Norway).

Acknowledgments: We would like to thank Federica Zanellato for the precious help in conducting the physiological analyses.

Conflicts of Interest: The authors declare no conflict of interest.

\section{References}

1. Karamesouti, M.; Detsis, V.; Kounalaki, A.; Vasiliou, P.; Salvati, L.; Kosmas, C. Land-use and land degradation processes affecting soil resources: Evidence from a traditional Mediterranean cropland. Catena 2015, 132, 45-55. [CrossRef]

2. Shaviv, A.; Mikkelsen, R.L. Controlled-release fertilizers to increase efficiency of nutrient use and minimize environmental degradation-A review. Fertil. Res. 1993, 35, 1-12. [CrossRef]

3. Trivedi, P.; Delgado-Baquerizo, M.; Anderson, I.C.; Singh, B.K. Response of soil properties and microbial communities to agriculture: Implications for primary productivity and soil health indicators. Front. Plant Sci. 2016, 7, 990. [CrossRef] [PubMed]

4. Canellas, L.P.; Olivares, F.L.; Aguiar, N.O.; Jones, D.; Nebbioso, A.; Mazzei, P.; Piccolo, A. Humic and fulvic acids as biostimulants in horticulture. Sci. Hortic. 2015, 196, 15-27. [CrossRef]

5. Yakhin, O.I.; Lubyanov, A.A.; Yakhin, I.A.; Brown, P.H. Biostimulants in Plant Science: A Global Perspective. Front. Plant Sci. 2017, 7, 2049. [CrossRef] [PubMed]

6. Colla, G.; Nardi, S.; Cardarelli, M.; Ertani, A.; Lucini, L.; Canaguier, R.; Rouphael, Y. Protein hydrolysates as biostimulants in horticulture. Sci. Hortic. 2015, 196, 28-38. [CrossRef]

7. Nardi, S.; Pizzeghello, D.; Schiavon, M.; Ertani, A. Plant biostimulants: Physiological responses induced by protein hydrolyzed-based products and humic substances in plant metabolism. Sci. Agric. 2016, 73, 18-23. [CrossRef]

8. Du Jardin, P. Plant biostimulants: Definition, concept, main categories and regulation. Sci. Hortic. 2015, 196, 3-14. [CrossRef]

9. Calvo, P.; Nelson, L.; Kloepper, J.W. Agricultural uses of plant biostimulants. Plant Soil 2014, 383, 3-41. [CrossRef] 
10. Nardi, S.; Carletti, P.; Pizzeghello, D.; Muscolo, A. Biological activities of humic substances. In Biophysico-Chemical Processes Involving Natural Nonliving Organic Matter in Environmental Systems; Part, I. Fundamentals and Impact of Mineral-Organic-Biota Interactions on the Formation, Transformation, Turnover, and Storage of Natural Nonliving Organic Matter (NOM); Senesi, N., Xing, B., Huang, P.M., Eds.; John Wiley \& Sons: Hoboken, NJ, USA, 2009; Volume 2, pp. 305-339.

11. Nardi, S.; Ertani, A.; Francioso, O. Soil-root cross-talking: The role of humic substances. J. Plant Nutr. Soil Sci. 2017, 180, 5-13. [CrossRef]

12. Zandonadi, D.B.; Santos, M.P.; Dobbss, L.B.; Olivares, F.L.; Canellas, L.P.; Binzel, M.L.; Okorokova, A.L.; Façanha, A.R. Nitric oxide mediates humic acids-induced root development and plasma membrane $\mathrm{H}^{+}$-ATPase activation. Planta 2010, 231, 1025. [CrossRef]

13. Montoneri, E.; Adani, F.; Genevini, P.L.; Ricca, G.; Cherubini, S.; Spitaleri, C. Polyalkylphenyl-sulphonic acids with acid groups of variable strength from animal-vegetable wastes. Waste Manag. 2004, 24, 513-522. [CrossRef]

14. Gargulak, J.D.; Lebo, S.E. Commercial use of lignin-based materials. In Lignin: Historical, Biological and Haterials Perspectives; Glass, W.G., Northey, R.A., Schultz, T.P., Eds.; ACS Symposium Series 742; American Chemical Society: Washington, DC, USA, 2000; Volume 15, pp. 2-559.

15. Lutnaes, B.F.; Myrvold, B.O.; Lauten, R.A.; Endeshaw, M.M. 1H and 13C NMR data of benzylsulfonic acids model compounds for lignosulfonate. Magn. Reson. Chem. 2008, 46, 299-305. [CrossRef]

16. McGovern, J.N. Pulp and Paper: Chemistry and Chemical Technology, 3rd ed.; Casey, J.P., Ed.; Wiley: New York, NY, USA, 1980; Volume 4.

17. Ertani, A.; Francioso, O.; Tugnoli, V.; Righi, V.; Nardi, S. Effect of commercial lignosulfonate-humate on Zea mays L. metabolism. J. Agric. Food Chem. 2011, 59, 11940-11948. [CrossRef]

18. Matsushita, Y. Conversion of technical lignins to functional materials with retained polymeric properties. J. Wood Sci. 2015, 61, 230-250. [CrossRef]

19. Cieschi, M.T.; Lucena, J.J. Iron and Humic Acid Accumulation on Soybean Roots Fertilized with Leonardite Iron Humates under Calcareous Conditions. J. Agric. Food Chem. 2018, 66, 13386-13396. [CrossRef]

20. Kovács, K.; Czech, V.; Fodor, F.; Solti, A.; Lucena, J.J.; Santos-Rosell, S.; Hernández-Apaolaza, L. Characterization of Fe-Leonardite complexes as novel natural iron fertilizers. J. Agric. Food Chem. 2013, 61, 12200-12210. [CrossRef]

21. Aguirre, E.; Leménager, D.; Bacaicoa, E.; Fuentes, M.; Baigiorri, R.; Zamarreño, A.M.; García-Mina, J.M. The root application of a purified leonardite humic acid modifies the transcriptional regulation of the main physiological root responses to Fe deficiency in Fe-sufficient cucumber plants. Plant Physiol. Biochem. 2009, 47, 215-223. [CrossRef]

22. Kulikova, N.A.; Stepanova, E.V.; Koroleva, O.V. Mitigating activity of humic substances: Direct influence on biota. In Use of Humic Substances to Remediate Polluted Environments: From Theory to Practice; Springer: Dordrecht, The Netherlands, 2005; pp. 285-309.

23. Billingham, K. Humic products potential or presumption for agriculture? Can humic products improve my soil? In Proceedings of the 27th Annual Conference of the Grassland Society of NSW Inc., Orange, NSW, Australia, 24-26 July 2012; Harris, C., Lodge, G., Waters, C., Eds.; Grassland Society of NSW Inc.: Wagga, Australia, 2012; pp. 43-50.

24. Mikkelsen, R.L. Humic materials for agriculture. Better Crop 2005, 89, 6-10.

25. Lobartini, J.C.; Tan, K.H.; Rema, J.A.; Gingle, A.R.; Pape, C.; Himmelsbach, D.S. The geochemical nature and agricultural importance of commercial humic matter. Sci. Total Environ. 1992, 113, 1-15. [CrossRef]

26. Gaur, A.C.; Bhardwaj, K.K.R. Influence of sodium humate on the crop plants inoculated with bacteria of agricultural importance. Plant Soil 1971, 35, 613-621. [CrossRef]

27. Mora, V.; Bacaicoa, E.; Baigorri, R.; Zamarreno, A.M.; Garcia-Mina, J.M. NO and IAA key regulators in the shoot growth promoting action of humic acid in Cucumis sativus L. J. Plant Growth Regul. 2014, 33, 430-439. [CrossRef]

28. Iakimenko, O.S. Commercial humates from coal and their influence on soil properties and initial plant development. In Use of Humic Substances to Remediate Polluted Environments: From Theory to Practice; Springer: Dordrecht, The Netherlands, 2005; pp. 365-378.

29. Schulz, H.; Baranska, M. Identification and quantification of valuable plant substances by IR and Raman spectroscopy. Vib. Spectrosc. 2007, 43, 13-25. [CrossRef] 
30. Suganuma, S.; Nakajima, K.; Kitano, M.; Yamaguchi, D.; Kato, H.; Hayashiet, S. Hydrolysis of cellulose by amorphous carbon bearing $\mathrm{SO} 3 \mathrm{H}, \mathrm{COOH}$, and $\mathrm{OH}$ groups. J. Am. Chem. Soc. 2008, 130, 12787-12793. [CrossRef]

31. Semwal, S.; Gaur, R.; Mukherjee, S.; Chopra, A.; Gupta, R.P.; Kumar, R.; Tuli, D.K. Structural features of dilute acid pretreated Acacia mangium and impact of sodium sulfite supplementation on enzymatic hydrolysis. Sustain. Chem. Eng. 2016, 4, 4635-4644. [CrossRef]

32. Nadji, H.; Diouf, P.N.; Benaboura, A.; Bedard, Y.; Riedl, B.; Stevanovic, T. Comparative study of lignins isolated from Alfa grass (Stipa tenacissima L.). Bioresour. Technol. 2009, 100, 3585-3592. [CrossRef]

33. Hsu, T.C.; Guo, G.L.; Chen, W.H.; Hwang, W.S. Effect of dilute acid pretreatment of rice straw on structural properties and enzymatic hydrolysis. Bioresour. Technol. 2010, 101, 4907-4913. [CrossRef]

34. Hergert, H.L. Infrared spectra, In Lignins: Occurrence, Formation, Structure and Reactions; Sarkanen, K.V., Ludwig, C.H., Eds.; John Wiley \& Sons, Inc.: New York, NY, USA, 1971; pp. 267-296.

35. Ozgenc, O.; Durmaz, S.; Hakki Boyaci, I.; Eksi-Kocak, H. Determination of chemical changes in heat-treated wood using ATR-FTIR and FT Raman spectrometry. Spectrochim. Acta Part A Mol. Biomol. Spectrosc. 2017, 171, 395-400. [CrossRef]

36. Séné, C.; McCann, M.C.; Wilson, R.H.; Crinter, R. Fourier-Transform Raman and Fourier-Transform lnfrared Spectroscopy. Plant Physiol. 1994, 106, 1623-1631.

37. Synytsya, A.; Bleha, R.; Synytsya, A.; Pohl, R.; Hayashi, K.; Yoshinaga, K.; Nakano, T.; Hayashi, T. Mekabu fucoidan: Structural complexity and defensive effects against avian influenza A viruses. Carbohydr. Polym. 2014, 111, 633-644. [CrossRef]

38. Marinval, N.; Saboural, P.; Haddad, O.; Maire, M.; Bassand, K.; Geinguenaud, F.; Djaker, N.; Ben Akrout, K.; Lamy de la Chapelle, M.; Robert, R.; et al. Identification of a pro-angiogenic potential and cellular uptake mechanism of a LMW highly sulfated fraction of fucoidan from Ascophyllum nodosum. Mar. Drugs 2016, 14, 185. [CrossRef]

39. Mora, V.; Baigorri, R.; Bacaicoa, E.; Zamarrenõ, A.M.; García-Mina, J.M. The humic acid induced changes in the root concentration of nitric oxide, IAA and ethylene do not explain the changes in root architecture caused by humic acid in cucumber. Environ. Exp. Bot. 2012, 76, 24-32. [CrossRef]

40. Mora, V.; Bacaicoa, E.; Zamarrenõ, A.M.; Aguirre, E.; Garnica, M.; Fuentes, M.; García-Mina, J.M. Action of humic acid on promotion of cucumber shoot growth involves nitrate-related changes associated with the root-to-shoot distribution of cytokinins, polyamines and mineral nutrients. J. Plant Physiol. 2010, 167, 633-642. [CrossRef]

41. Pizzeghello, D.; Nicolini, G.; Nardi, S. Hormone-like activity of humic substances in Fagus sylvaticae L. forests. New Phytol. 2001, 151, 647-657. [CrossRef]

42. Muscolo, A.; Sidari, M.; Francioso, O.; Tugnoli, V.; Nardi, S. The auxin-like activity of humic substances is related to membrane interactions in carrot cell cultures. J. Chem. Ecol. 2007, 33, 115-129. [CrossRef]

43. Pizzeghello, D.; Zanella, A.; Carletti, P.; Nardi, S. Chemical and biochemical characterization of dissolved organic matter from Silver fir and beech forest soils. Chemosphere 2006, 65, 190-200. [CrossRef]

44. Muscolo, A.; Sidari, M.; Attinà, E.; Francioso, O.; Tugnoli, V.; Nardi, S. Biological activity of humic substances is related to their chemical structure. Soil Sci. Soc. Am. J. 2007, 71, 75-85. [CrossRef]

45. Jannin, L.; Arkoun, M.; Ourry, A.; Laîné, P.; Goux, D.; Garnica, M.; Fuentes, M.; San Francisco, S.; Baigorri, R.; Cruz, F.; et al. Microarray analysis of humic acid effects on Brassica napus growth: Involvement of N, C and S metabolisms. Plant Soil 2012, 359, 297-319. [CrossRef]

46. Vance, C.P.; Gantt, J.S. Control of nitrogen and carbon metabolism in root nodules. Physiol. Plant. 1992, 85, 266-274. [CrossRef]

47. Forde, B.G. Nitrate transporters in plants: Structure, function and regulation. BBA-Biomembr. 2000, 1465, 219-235. [CrossRef]

48. Wang, M.; Shen, Q.; Xu, G.; Guo, S. New insight into the strategy for nitrogen metabolism in plant cells. Int. Rev. Cell Mol. Biol. 2014, 310, 1-37.

49. Ertani, A.; Schiavon, M.; Nardi, S. Transcriptome-wide identification of differentially expressed genes in Solanum lycopersicon L. in response to an alfalfa-protein hydrolysate using microarrays. Front. Plant Sci. 2017, 8, 1159. [CrossRef] 
50. Lattanzio, V.; Lattanzio, V.M.T.; Cardinali, A. Role of phenolics in the resistance mechanisms of plants against fungal pathogens and insects. In Phytochemistry Advances in Research; Imperato, F., Ed.; Research Signpost: Kerala, India, 2006; pp. 23-67.

51. Vermerris, W.; Nicholson, R. Phenolic compound biochemistry. In The Role of Phenols in Plant Defense; Springer: Dordrecht, The Netherlands, 2006; pp. 211-234.

52. Chen, F.; Tholl, D.; Bohlmann, J.; Pichersky, E. The family of terpene synthases in plants: A mid-size family of genes for specialized metabolism that is highly diversified throughout the kingdom. Plant J. 2011, 66, 212-229. [CrossRef]

53. Zhang, F.P.; Yang, Q.Y.; Zhang, S.B. Dual effect of phenolic nectar on three floral visitors of Elsholtzia rugulosa (Lamiaceae) in SW China. PLoS ONE 2016, 11, e0154381. [CrossRef]

54. Di Marco, G.; D'Ambrosio, N.; Giardi, M.T.; Massacci, A.; Tricoli, D. Photosynthetic properties of leaves of a yellow green mutant of wheat compared to its wild type. Photosynth. Res. 1989, 21, 117-122.

(C) 2019 by the authors. Licensee MDPI, Basel, Switzerland. This article is an open access article distributed under the terms and conditions of the Creative Commons Attribution (CC BY) license (http://creativecommons.org/licenses/by/4.0/). 